\title{
The controversy dialogue leading towards Jesus' severe response in Matthew 23
}

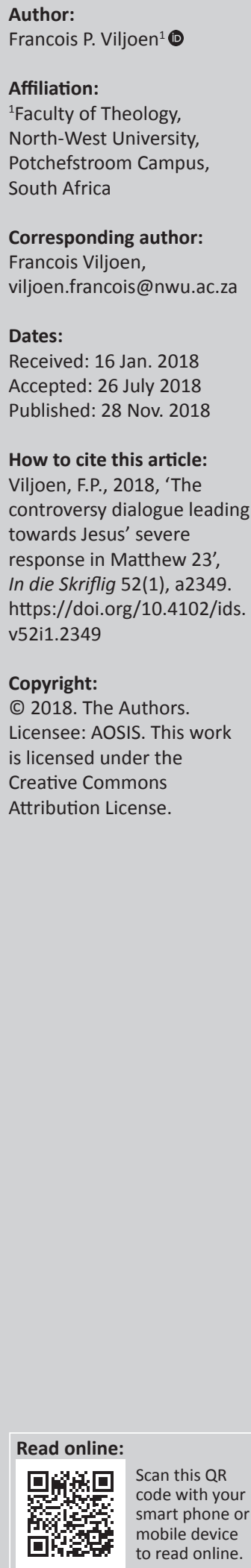

Scholars have described Matthew 23 as the 'unloveliest' chapter and 'bleakest spot' in the Gospel. It might seem that this chapter does not fit into the overall structure and plot of the Gospel, and that it is a clumsy redactional addition being untypical of the Matthean Jesus. This article recognises the severe nature of this chapter but argues that it does fit into the developing tension between the Jewish leaders and Jesus within the Gospel. It is demonstrated how it forms part of a narrative where Jesus is involved in constant and intensifying controversy dialogue with these leaders. The leaders constantly challenge Jesus with increasing intensity which eventually led towards Jesus's climactic response in this chapter.

\section{Introduction}

While conflict between Jesus and the religious leaders is central throughout Matthew's plot, ${ }^{1}$ the conflict intensifies significantly in the final discourses of Matthew 23-25 (Keener 1999:536; Repschinski 2000). Luz (1968:96) goes so far as to remark: 'With its woes and its unjust wholesale judgement about scribes and Pharisees, Matthew 23 is the unloveliest chapter in the Gospel', a sentiment Viviano (1990:3) shares. Carter (2000:66) describes it as 'the bleakest spot' in Matthew's Gospel. Esler (2015:39-59) opines that this challenging text is best understood in terms of intergroup conflict between a branch of the Christ-movement and a Judean outsider group. He investigates the passage in terms of social identity theory and describes Matthew 23 as one of the most extreme forms of intergroup conflict. ${ }^{2}$ He opines that this passage is the product of the evangelist and not of the historical Jesus, as he regards the polemic as untypical of the historical Jesus (Esler 2015:56). Kümmel (1967:146-147) remarks that the zealous polemic in Matthew 23 distorts the reality and spirit of Jesus as portrayed in the Gospel.

This raises the question if and how Matthew 23 fits into the overall structure and plot of the first Gospel. This article argues that, though sounding harsh, this chapter with its severe woe-sayings does indeed fit into the developing plot of the Gospel. This article investigates the growing tension between teachers of the Law and the Pharisees, and Jesus in the text preceding Matthew 23. It is demonstrated that the religious leaders severely challenge Jesus's authority to teach in public in consecutive scenes (Mt 21:23-22:46). These challenges are balanced by Jesus's immediate responses which culminate in his final public response with his pronouncements of judgement on the Pharisees and Jerusalem (Mt 23:1-24:2).

This challenge and response seem to fit into the scheme of honour and shame societies, as in New Testament times. Honour or shame is acquired by the conduct of a person, but also by people's recognition of it. In such communities it was a common phenomenon to challenge the honour of an opponent in a controversy dialogue (Streitgespräch) to shame such a person. A central phenomenon to a Streitgespräch is the interaction of challenge and riposte (Malina \& Rohrbaugh 2003:42; Repschinski 2000:262-272; Witherington 2006:47). Bultmann (1963:11-61) identified four elements in Streitgespräche: (1) they provide an action or attitude; (2) they are used by opponents; (3) it happens in an attack in the form of a question or accusation; and (4) the attack is followed by a reply, often including a counter question or a quotation from Scripture. Such a challenge had to be played in public to be effective in gaining honour or imposing shame. Matthew 23 with its preceding chapters serves as a clear example of such a Streitgespräch. This article demonstrates how the Jewish leaders in Matthew 21-22 challenge Jesus with the intention to undermine his reputation 1.Kingsbury (1995:169) regards the religious leaders more central to Matthew's plot than the disciples, as this conflict forms the focus of
the plot. Keener (2002:103) concurs and opines that this may be because the successors of the teachers of the Law and the Pharisees were the main Jewish opposition that the addressees faced in Syria-Palestine.

2.Matthew's Gospel reflects specific intergroup tensions, underlying conflicts and concerns (Foster 2004:3; Saldarini 1994:12; Stanton 1993:26) that fit into the history of the complex Jewish-Christian relations of the first century (Harlow 2012:391; Sim 1999:186; Viljoen 2016:1-8). 
and how Jesus responds in a manner that measures up to their challenge. This response climaxes in with Matthew 23.

Once the place of the woes and eschatological discourse (Mt 23-25) is defined in relation to the other discourses in this Gospel, the increasing confrontation during the first four days of the Passion week in Matthew 21-22 is argued. It is demonstrated how this confrontation commences with Jesus' humble, yet royal, entry into Jerusalem, that is followed by the judgement of the temple and the fig tree. This action of Jesus exposes the opposing attitude of the Jewish leaders and entices their anger. This leads towards controversy dialogues (Streitgespräche) between these leaders and Jesus in the temple court. This controversy dialogue climaxes with Jesus' severe response to the teachers of the Law and the Pharisees.

\section{The woes and eschatological discourse as the final Matthean discourse}

The woes (Mt 23) followed by the eschatological discourse (Mt 24-25) form the last of Matthew's five great discourses in this Gospel: the Sermon on the Mount (Mt 5-7), the missionary charge (Mt 10:5-42), the parables discourse (Mt 13:3-52), instructions to the community (Mt 18:3-35), and the woes and eschatological discourse (Mt 23-25) (Riesner 1978:177-178). Combrink (1983:61-90) identifies a chiastic structure between these discourses: the Sermon on the Mount (Mt 5-7) is parallel to the woes and the eschatological discourse (Mt 23-25). The missionary charge (Mt 10) is parallel to the community discourse (Mt 18). The parables discourse (Mt 13) is framed by the above-mentioned parallels (cf. Keener 1999:535; Osborne 2010:831; Viviano 1990:9). The symmetry between the first and last discourses is apparent, and they frame Jesus' public ministry. While the first great discourse opens with blessings

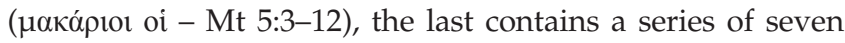

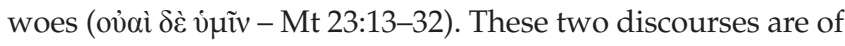
similar length. Both discourses are associated with a mountain and Jesus takes the seated position of a teacher (Mt 5:2; 24:3; Gundry 1994:453; Osborne 2010:831). Jesus is presented as the new Moses. As Moses came down the mountain to present the Law, Jesus went up the mountain to teach the Law authoritatively (Sermon on the Mount-Mt 5:1), and to expose false and hypocritical practices regarding the Law on Mount of Olives (Eschatological Discourse - Mt 24:3).

Matthew sets the scene with Jesus in the honorary position of the authoritative teacher and ruler.

\section{Increasing confrontation during first four days of the Passion week (Mt 21:1-25:46)}

This final discourse is embedded in a narrative ${ }^{3}$ where Jesus is in constant confrontation with the religious leaders in

3.This narrative is kept together with two inclusions: a reference to "Mount of Olives (21:1 and 24:3) and the statement: 'Blessed is He who comes in the name of the Lord!' (Mt 21:9 and 23:39).
Jerusalem (Talbert 2010:245). The continuous theme of judgement is significant and particularly intense in this discourse.

Jesus' journey to Jerusalem is described in Matthew 19-20 and the beginning of Matthew 21 describes how he enters the place of his destiny. The powers of darkness are set to erupt as the Passion narrative commences (Osborne 2010:751). Matthew 21:1-22:46 describes the intense disputes during the first four days of the Passion week, followed by the woes and eschatological discourse in Matthew 23-25.

Matthew 21:1-25:46 forms a literary unit (Garland 1979). Wilson (2004:69) demonstrates how the theme of the coming king, first humbly (Mt 21:1-17) and then in glory (Mt 25:31-46), forms an inclusio around Matthew 21-25. This unit is further defined by the citation of Psalm 118:26 in Matthew 21:9 and again in 23:39 to form a bracket denoting these chapters (Viviano 1990:7). The central message seems to be that the teachers of the Law and the Pharisees, who put themselves on a legal and moral high ground and who constantly challenge the authority of Jesus as teacher, are on trial themselves. Their hypocrisy and unrighteousness will be exposed, and they will be judged for it.

This major literary unit is composed of two rhetorical units (Scholtz 2015:1). The first unit comprises Matthew 21:1-23:39,

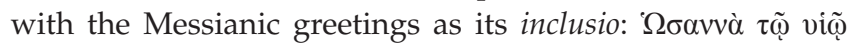

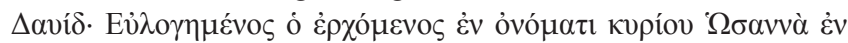

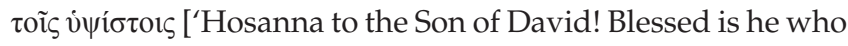
comes in the name of the Lord! Hosanna in the highest

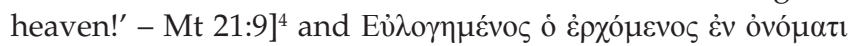
кupíov [Blessed is he who comes in the name of the Lord - Mt 23:39]. ${ }^{5}$ The second unit comprises Matthew 24:1-25:46, with its inclusio being Jesus exiting from the temple and subsequently sitting on the Mount of Olives, juxtaposed with his return to the Mount of Olives and his sitting on the throne of his glory as king and judge (Mt 24:1-3; 25:31-46; cf. Zch 14:4; Ac 1:9-12). Although part of a larger rhetorical unit (21:1-25:46), the change in setting from the temple to the Mount of Olives, the change in audience to only Christ's disciples, and the distinct (but related) themes separate Matthew 24:1-25:46 as rhetorical unit (cf. Carson 1995:469; France 2007:768; Turner 2008:543-544). Matthew 21:1-23:39 describes the judgement of the religious leaders and $\dot{\eta} \gamma \varepsilon v \varepsilon \dot{\alpha}$

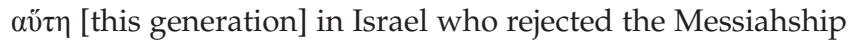
of Jesus at his first coming. In Matthew 24:1-25:46 the scope moves to a worldwide judgement of all nations who reject the coming king at the end of the age (cf. Blomberg 1992:351; Wilson 2004:254-255).

The current investigation is limited to the first of these two rhetorical units. The sections of this unit can broadly be identified as follows (as seen in Box 1: Sections describing increasing conflict), from which the growing conflict between the Jewish leaders and Jesus becomes evident.

4.The Messianic greeting of Matthew 21:9 is taken from Psalm 118:25-26.

5.The shorter greeting in Matthew 23:39 is a quotation from Psalm 118:26 only. 
BOX 1: Sections describing increasing conflict.

Commencement of the Passion week (Mt 21:1-22)
Jesus' humble entry and enthusiastic acclaim (Mt 21:1-11)
Judgement of the temple (Mt 21:12-17)
Cursing of the fig tree (Mt 21:18-22)
Controversies in the temple court (Mt 21:23-22:46)
Introduction to the controversies (Mt 21:23-27)
Challenge of Jesus's authority (Mt 21:23-27)
Three judgement parables (Mt 21:28-22:14)
1. Parable of two sons (Mt 21:28-32)
2. Parable of the wicked tenants (Mt 21:33-46)
3. Parable of the wedding banquet (Mt 22:1-14)
Three challenging questions posed by religious leaders (Mt 22:15-40)
1. Question on paying taxes to the Caesar (Mt 22:15-22)
2. Question on marriage after resurrection (Mt 22:23-33)
3. Question on the greatest commandment (Mt 22:34-40)
Decisive question posed by Jesus (Mt 22:41-46)
Whose son is the Christ (Mt 22:41-46)
Guilt and judgement of Israel (Mt 23:1-25:46)
Seven woes upon the teachers of the Law and the Pharisees (Mt 23:1-39)
Eschatological discourse (Mt 24-25)

Seven woes upon the teachers of the Law and the Pharisees (Mt 23:1-39)

Eschatological discourse (Mt 24-25)

\section{Commencement of the Passion week (Mt 21:1-22)}

The description of the Passion week commences with Jesus' humble entry into Jerusalem, where he is met with enthusiastic acclaim (Mt 21:1-11). This entry illuminates his lowliness, but also his authority (Bruner 2007:353; Gundry 1994:409). Jesus' entry parodies the Roman triumphal entries (Carter 2000:67) and echoes the entry of Solomon ${ }^{6}$ as Jewish royal figure and all wise king, riding on a donkey into town to be anointed as David's successor (1 Ki 1:32-40). Reference is made to Zechariah 9:9, a text that was generally acknowledged as Messianic (Keener 2002:97). Jesus enters the city triumphal as Zechariah's king of peace. This Solomonic tradition in 1 Kings 1 and the message of the Messiah in Zechariah 9:9-10 guide the way Matthew portrays Jesus (Witherington 2006:387-389). The narrative portrays Jesus as the wise king and Messiah, one whose wisdom exceeds that of Solomon. The narrative clearly establishes Jesus' wise and authoritative position, but his wisdom is increasingly challenged by the Jewish religious leaders.

Jesus' superior stance is demonstrated with his cleansing of the temple immediately following his entry of the city (Mt 21:12-17). Jesus is depicted in the form of an enacted parable as the righteous and mighty judge who accuses the practices of religious leadership in the temple courts. ${ }^{7} \mathrm{He}$ brings wholeness and new life as he heals the blind and lame who were excluded from the temple (Carter 2000:67). Obviously, this cleansing was a public insult to the religious elite who exercised control over the temple. Jesus challenged their honour, which obviously would evoke retaliation from them (Keener 2002:98).

The scene to follow is that of the cursing of the fig tree 8 (Mt 21:18-22), the only negative miracle in the Gospel, which

6.The name Solomon has symbolic meaning, as it is derived from shalom. Solomon was David's peace child and royal figure who was the wise king of peace (Witherington 2006:388)

7.According to Matthew 26:61, two chief priests or members of the Sanhedrin mention Jesus' words of the temple being destroyed and rebuilt. 2 Samuel 7:13 promised that the Davidic messiah would one day build the eschatological temple as Solomon had done before (Witherington 2006:396).

8.In Micah 7:1 a fruitless and barren fig tree symbolises morally and spiritually barren people of God. pictures the coming judgement of Israel. The link between the cleansing of the temple and the cursing of the fig tree makes the incidents most dramatic symbols of God's rejection of the Jewish religious leaders (Gundry 1994:415). The cursed fig tree represents 'this wicked and adulterous generation' in Israel (Toussaint 1980:245) on whom 'all these things' of Matthew 23:34-36 come because they have rejected the true Christ. The suddenness of the withering of the fig tree leaves the disciples amazed. Jesus is to be recognised as the ultimate judge.

Jesus' actions in this section set the table for the controversy dialogues to follow. Jesus is the wise prophet and teacher, similar but greater than Solomon the temple builder, for it is Jesus who is offended by temple practices and as judge announces the end of the corrupt temple and religious leaders (Witherington 2006:389).

\section{Controversy dialogues in the temple court (Mt 21:23-22:46)}

Following Jesus' entry into Jerusalem, the events of two days are narrated with Jesus entering and leaving the temple (Mt 21:12-22 and 21:23-24:2). As Jesus is about to exit the temple, he does not refer to it as ó oĩcós $\mu$ ov [my house] any more like in Matthew 21:13, but aloofly as ó oĩ which will be left desolate. Every time Jesus leaves the temple, he makes a severe pronouncement of judgement (Mt 21:199 and 24:1, 2). ${ }^{10}$ The theme of judgement then continues in following passages that deal with the final judgement (Mt 24:3-25:46). Matthew 23 forms the conclusion to Jesus' second day at the temple (Mt 21:23-24:2), but like a Janus-like hinge, also forms the introduction to the Olivet discourse on the end time judgement (Mt 24-25; Viviano 1990:8). The theme of judgement on the religious establishment (Mt 23:12-33) and the demise of the temple (Mt 23:35-38) ${ }^{11}$ continues in Matthew 24:24-25:30 and 24:1-3, 15 respectively (Keener 1999:535).

\section{Challenge of Jesus' authority (Mt 21:23-27)}

The religious leaders who were publicly dishonoured tried to recover their honour by publicly challenging Jesus (Keener 2002:99). As was typical of debate in antiquity, challenging questions are met with clever responses. Matthew 21:23-22:46 deals with various challenges by the religious leaders to dishonour Jesus and to contest his authority to teach. With challenging questions, the religious leaders attempt to

9.Matthew 21:19: 'Seeing a fig tree by the road, he went up to it but found nothing on it except leaves. Then he said to it, 'May you never bear fruit again!' Immediately the tree withered'.

10.Matthew 24:1-2: 'Jesus left the temple and was walking away when his disciples came up to him to call his attention to its buildings. 'Do you see all these things?' he asked. 'Truly I tell you, not one stone here will be left on another; everyone will be thrown down".

11.While the Jerusalem temple was still standing, it functioned as the main institution of the Jewish society (Wright 2013:310). Those in control of the temple established policies for the daily practices of Jews, but not all Jews accepted them willingly policies for the daily practices of Jews, but not all Jews accepted them willingly
(Brown 1997:75). During the latter part of the Second Temple period the broader society increasingly mistrusted these persons who held powerful religious and society increasingly mistrusted these persons who held powerful religious and
political positions, regarding them as fraudulent (Saldarini 1994:112; Wright 2013:310) 
expose Jesus as an unworthy teacher, though without success. The rivals Jesus battled against became increasingly more skilled; it began with the chief priests and elders (Mt 21:23), the disciples of the Pharisees and Herodians (Mt 22:15), Sadducees (Mt 22:23) and an expert of the Law (Mt 22:35) (Simmonds 2009:338).

The challenge of Jesus' authority opens with the question of the chief priests and elders of the people on the ground of Jesus' authority to teach, that is to act as a rabbi (Mt 21:23), while the question in Mark revolves around Jesus' authority to cleanse the temple (Mk 11:28). Jesus responds by arguing that his authority has the same origin as that of John, namely from God (Mt 21:24-25). The chief priests and elders of the people are unable to respond, and in such a way Matthew emphasises the superior authority and knowledge of Jesus.

\section{Three judgement parables as response (Mt 21:28-22:14)}

As response to the challenge posed by the Jewish leaders, the narrative proceeds with Jesus telling three judgement parables, namely of the two sons (Mt 21:28-32), the wicked tenants (Mt 21:33-46) and of the wedding banquet (Mt 22:1-14). The parable of the two sons (Mt 21:28-32) is unique to Matthew and opens a series of these three parables. Though the second and third parables have parallels, they are not side-by-side as in Matthew. All three of these parables deal with the way Jesus is rejected (Gundry 1994:421). By arranging these parables consecutively, Matthew emphasises the controversy and rejection that took place.

The parable of the two sons (Mt 21:28-32) falls out in two parts, the polemical parable (Mt 21:28-30) and its allegorical application (Mt 21:31-32; Davies \& Allison 2004:164). The first son represents the tax collectors and sinners who repented and came to obey God through the ministry of John. The second son represents the chief priests and elders, who despite their religious profession, disobeyed God by not believing John. The second half opens with Jesus' polemic question on which of the two sons in effect did the will of the father. The priests and the elders approve behaviour that is unlike their own. The parable concludes with the question of why the chief priests and elders do not repent as the first son, and why they did not believe John.

The parable of wicked tenants (Mt 21:33-46) at first tells the parable as such (Mt 21:33-39), followed by the application (Mt 21:40-46). Jesus reminds the religious leaders that they are mere custodians of God. This parable combines the motif of God being the benevolent landowner with that of the religious leaders who challenge his honour and test his patience. The murder of the prophets finds its climax in the rebellion and killing of God's Son. The conclusion of the parable is filled with irony (Mt 21:45-46; Davies \& Allison 2004:187). Shortly after answering Jesus on what would happen with those who killed the owner's son, they realise that Jesus is referring to them. Their response is to scheme how they could get rid of Jesus, in that way inviting the same fate over themselves as that of the wicked tenants.

The parable of the wedding banquet (Mt 22:1-14), which has a parallel in Luke, carries the polemic with the Jewish leaders further. The parable also falls out in the parable (Mt 22:1-13b) and the application (Mt 22:13c-14). The parable contains two parallel sequences (Mt 22:2-7 and 8-13), each opening with invitations, and closing with punishment. The whole parable is dominated by the speech of the king, indicating his authority (Davies \& Allison 2004:194). The reader automatically identifies the king as God, and his son, the bridegroom, as Jesus. The royal wedding represents the eschatological banquet, and the murder of the servants, an absurdly inexplicable response to the king's repetitive kind invitations, represents the murder of the prophets and of Jesus.

\section{Three challenging questions posed by the Jewish leaders (Mt 22:15-40)}

The controversy intensifies with the Jewish leaders' response to these three parables. They pose three hostile questions to Jesus, namely on paying taxes to the Caesar (Mt 22:15-22), on

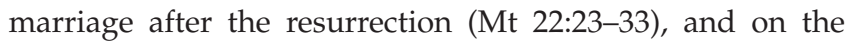
greatest commandment (Mt 22:34-40). All three of these scenes portray the offensive character of these leaders.

Firstly, the Pharisees and Herodians challenge Jesus (Mt 22:15-22). They hypocritically address him as $\delta 1 \delta \alpha ́ \sigma \kappa \alpha \lambda \varepsilon$ [teacher] and ironically speak the truth about Jesus oif $\delta \alpha \mu \varepsilon v$

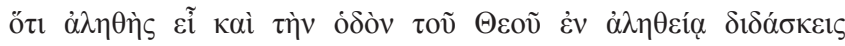
[we know that you are a man of integrity and that you teach the way of God in accordance with the truth; Mt 22:16]. ${ }^{12}$ Jesus gives no simple 'yes' or 'no' to their question, but instructs them to weigh the demands of God and the Caesar; they should render to the Caesar what belongs to him, and to God what belongs to him. Jesus does not only avoid a wellconceived trap, but also advances his teaching. Instead of trapping Jesus, the Pharisees and Herodians are trapped by him (Davies \& Allison 2004:216). They are unable to offer any rebuttal. They simply must accept their defeat. The reader realises that Jesus teaches with unparalleled authority.

Following the political question posed by the Pharisees and Herodians, the Sadducees follow with a theological riddle (Mt 22:23-33; Viljoen 2015:1-11). While these parties oppose each other regarding the resurrection, they are united in opposing Jesus. The Sadducees also address Jesus as $\delta 1 \delta \alpha ́ \sigma \kappa \alpha \lambda \varepsilon$ [teacher], yet again they do not seek instruction, but maliciously and sarcastically set a trap to undermine the honour of Jesus. Their question clearly implies that they reject the resurrection. Jesus treats their question as shameful

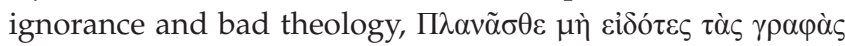

12.In Matthew, only Jesus' adversaries address him as teacher, namely the scribes, Pharisees, collectors of temple tax and the rich young man who goes away himaspointed with Jesus answer. People who respect and honour Jesus address him as Lord (kuplos; Repschinski 2000:274). When the Jewish leaders use "teacher", they do it in an ironic and sarcastic manner. If Jesus pretends to be a teacher (rabbi) who has adherents, let him then prove himself really to be a teacher. This form of address expresses their sinister intention to challenge Jesus' honour. 


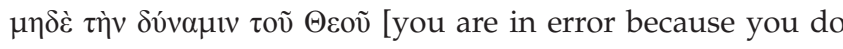
not know the Scriptures or the power of God; Mt 22:29; Davies \& Allison 2004:226]. This challenging scene is concluded by emphasising the authority of Jesus as teacher, as the crowds were astonished with his teaching, кaì

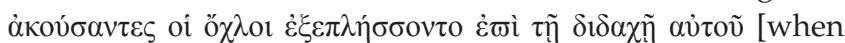
the crowds heard this, they were astonished at his teaching; Mt 22:33].

As representative of the Pharisees, one of them, an expert

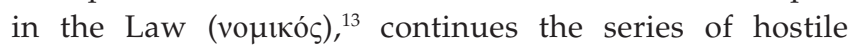
challenges with his question on the most important commandment (Mt 22:34-40). Notably Matthew turns the didactic narrative (Schulgespräch) of Mark on the greatest commandment (which has an amiable tone) into a conflict narrative (Streitgespräch). Again, Jesus responds in such a manner so as not to be trapped. He uses two summaries of the Law, the commandment to love God and to love one's neighbour.

\section{Decisive repost posed by Jesus (Mt 22:41-46)}

Concluding the three challenges, Jesus ends his defence in which he shows that he can answer the most difficult questions. He poses his repost as a question to his opponents about his identity, David's Son or David's Lord (Mt 22:41-46). His question is a riddle based on Psalm 110:1. The opponents are speechless as they are unable to answer Jesus, which forms a climax of the crescendo of the previous challenges. The result is that the debate with presumed learned opponents is ended and the table is set for the series of woe-sayings to follow.

The teaching authority of Jesus is clearly established and contrasted with the impotence of his opponents, who regard themselves as learned. By describing these disputes, Matthew confirms the authority and trustworthiness of Jesus in contrast with the lack of authority and deceitfulness of the Jewish religious leaders. Jesus clearly emerges as the victor in these disputes. Jesus' successful refutation of the challenges is mentioned repeatedly:

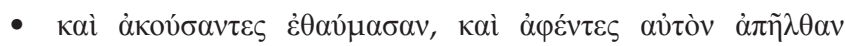
[when they heard this, they were amazed. Therefore they left him and went away; Mt 22:22];

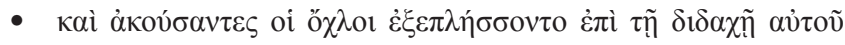
[when the crowds heard this, they were astonished at his teaching; Mt 22:33];

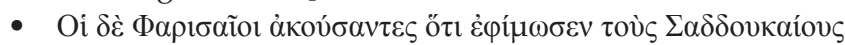

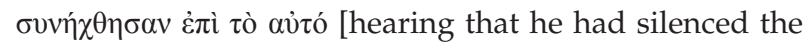
Sadducees, the Pharisees got together; Mt 22:34]; and

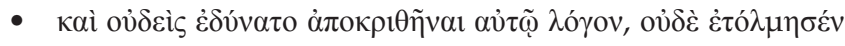

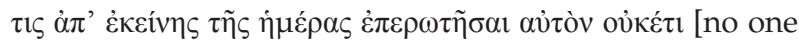
could say a word in reply, and from that day on no one dared to ask him any more questions; Mt 22:46].

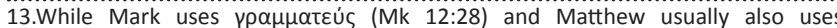

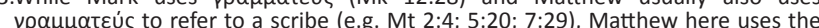
word voutkóc [expert of the Law]. As a matter of fact, this is the only time Matthew uses the word voutkós. Obviously, Matthew wants to emphasise that the uses the word voutkoc. Obviously, Matthew wants to emphasise that the
questioner should be regarded as a daunting interlocutor about this crucial legal questioner should be regarded as a daunting interlocutor about this crucial legal
issue (regarding the vouóc) at stake (Gerhardsson 1976:133; Osborne 2010:822).
Matthew emphasises Jesus' superiority by depicting the reactions of the disciples of the Pharisees and Herodians $(\mathrm{Mt}$ 22:22), the crowds (Mt 22:23) and the Pharisees (Mt 22:34) with emotive wording. The challenging Sadducees are silenced (Mt 22:34) and no one can say a word in reply or dares to ask him any more questions (Mt 22:46).

These disputes where Jesus emerges as the honourable victor set the table for Jesus' teaching in the temple about the Pharisees' bad teaching, hypocrisy and lack of righteousness, which would lead towards the judgement of the Pharisees and Jerusalem (Mt 23:1-24:2; Talbert 2010:250).

\section{Jesus' final response to the previous controversy dialogue (Mt 23)}

The Matthean controversy dialogue reaches its climax in Matthew 23. Jesus responds to the repetitive challenges posed in the foregoing sections. Matthew intensified the controversy also described in Mark 12:38-40, the probable source material for this chapter in Matthew (Davies \& Allison 2004:266). Matthew developed a lengthy polemic of 39 verses based on a mere three verses in Mark. This extended polemical discourse is unique to Matthew, with only a few parallels: Matthew 23:4 // Luke 11:46; Matthew 23:6-7a // Mark 12:38-39 and Luke 20:46-47; and Matthew 23:12 // Luke 14:11 and 19:14.

Matthew 23 falls out in three sections, each addressing a different audience (Osborne 2010:832). Jesus warns the crowds and the disciples against the teachers of the Law and the Pharisees (Mt 23:1-12), he addresses the teachers of the Law and the Pharisees directly in his criticism (Mt 23:13-36), and he addresses Jerusalem with sorrow, lamenting its imminent judgement (Mt 23:37-39). ${ }^{14}$

\section{Warning against the teachers of the Law and the Pharisees (Mt 23:1-12)}

In Matthew 23:1-12 Jesus publicly addresses the crowds who have heard how the Jewish religious leaders had challenged Jesus, and how he time and again refuted these challenges and wisely emerged as victor (Mt 22:22, 33, 34, 46). Jesus' profile is that of a wise and superior teacher.

Jesus tells the crowds what the teachers of the Law and the Pharisees do (Mt 23:1-7) and then proceeds to talk about what his disciples should do instead (Mt 23:8-12). It seems that the main idea is to contrast the pride and hypocrisy of the religious leaders with the modesty and willingness to serve as Jesus required from his followers (Osborne 2010:833).

14.Newport (1995:76-79) proposes that the source for Matthew $23: 2-31$ is a pre-70 CE Jewish-Christian tract, and that Matthew 23:32-39 is a later redaction. He argues that Matthew 23:2-31 exhibits an intra muros setting, while he assumes that Matthew writes from an extra muros position. He argues that Matthew 23:2-31 describes customs and practices of first-century Jews, which indicates an intra-Jewish debate. He regards the Sitz im Leben of this section the same as that of the Sermon on the Mount, and as being different to the rest of the Gospe (Newport 1995:157). In such a way Newport escapes the difficulty to fit this troublesome passage within the Gospel as a whole. However, as difficult it is to explain, this passage does form part of the text and needs interpretation contra the view of Newport. 
Jesus' criticism of the Jewish religious leaders is twofold (Davies \& Allison 2004:264; Talbert 2010:256). He depicts firstly their hypocritical teaching and conduct (Mt 23:2-4), and secondly their desire for public acclaim (Mt 23:5-7). The Pharisees claimed to be Moses' successors and therefore had the presumption that they were the official interpreters of the Torah who could speak with ultimate authority (Davies \& Allison 2004:268; Gundry 1994:454; Keener 2002:103; Mason 1990:363-381; Viviano 1990:11).

The Matthean Jesus argues that though the religious leaders claim to have the authority to interpret the Torah accurately, their lives testify to the opposite. He accuses them of insincere and untrustworthy teachings. He criticises their claim to be the most skilful interpreters of the Law by pointing out how their behaviour tells the opposite.

Jesus furthermore depicts the teachers of the Law and Pharisees as people who do things because of wrong motives (Mt 23:5-7; Talbert 2010:257). Within their honour and shame society, they sought honour through recognition by society (cf. De Silva 2004:125; Keener 2002:104). Jesus radically rejects this prevailing mode of conduct. Criticism of their teaching is pertinent, as Jesus accuses them of their fixation on attracting honour in their teaching by striving to be called 'Rabbi' in the public sphere (Esler 2015:46). They taught with insincere motives in mind.

In contrast to the vanity of the Pharisees and teachers of the Law as described in Matthew 23:1-7, Jesus proceeds to set out the antithetical behaviour required of discipleship in Matthew 23:8-12. These verses can be regarded as a small community rule on humility (Davies \& Allison 2004:265; Wiefel 1998:397). This rule signifies a contrast in community values between that of the Pharisees and teachers of the Law, and that of the followers of Jesus. These guidelines remind one of Matthew 18:1-4 $4^{15}$ and 20:25-28, ${ }^{16}$ where humility is mentioned as the basic premise of being a disciple. This rule is summed up with the saying: 'For whoever exalts himself will be humbled, and whoever humbles himself, will be exalted' (Mt 23:12; Esler 2015:48; Gundry 1994:459). These words clearly allude to the disgracing awaiting the boastful Jewish leaders.

\section{Woes on the teachers of the Law and the Pharisees (Mt 23:13-36)}

In Matthew 23:13-36 Jesus addresses the teachers of the Law and Pharisees with a series of seven 'woe-sayings'17 (ov̉aì $\delta \grave{\varepsilon}$

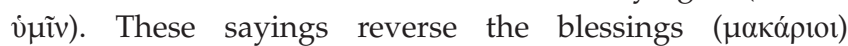
addressed to his disciples in Matthew 5:3-12. ${ }^{18}$ While Jesus communicates salvation to his disciples with his blessings,

15. Matthew 18:1-4: "Who is the greatest in the kingdom of heaven? ... Therefore whoever humbles himself like this child is the greatest in the kingdom of heaven'.

16. Matthew 20:25-28: '... whoever wants to become great among you, must be your servant, and whoever wants to be first must be your slave - just as the Son of Man did not come to be served, but to serve, and to give his life as ransom to many'.

17.Cf. Isaiah 5:8-23 and Luke 11:42-52 each with its series of six woe-sayings.

18.This contrast between judgements and blessings resembles the similar contrast found in the repetitive recital of the Levites in Deuteronomy 27-28. he communicates shame and judgement to the teachers of the Law and the Pharisees with these woes (Bruner 2007:443; Esler 2015:50). As in Matthew 11:21 ${ }^{19}$ these woe-sayings express proleptic condemnation, anticipating the downfall of the Jewish religious leaders.

Jesus repetitively charges the teachers of the Law and the

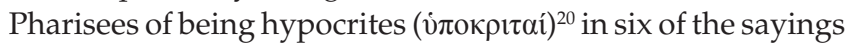
(Mt 23:13, 15, 23, 25, 27 and 29), and of being blind guides

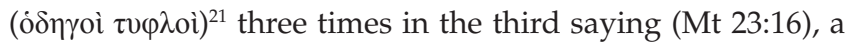
charge that is repeated in the fourth (Mt 23:24) and fifth saying (Mt 23:26). With irony and word play Jesus alludes to the Jewish Scriptures by remarking that the Pharisees regard themselves as guides for the blind (cf. Is 42:6-7), ${ }^{22}$ but in effect they are blind themselves. There is no use in arguing with them, as they are not able to see and discern the truth in other words they are not able to understand. Even worse, they increase the blindness of the people they guide. He accuses them of a false interpretation of the Law, being blind guides who mislead their followers (Mt 23:24; Bruner 2007:446).

The first three woe-sayings focus on the false teaching of the leaders (Mt 23:13-22), the next three mainly on their false practice (Mt 23:23-28), while the last saying accuses them of false security as if they were not guilty of killing the prophets (Mt 23:29-36; Bruner 2007:442).

The corrupt conduct of the addressees leads towards eschatological judgement. The teachers of the Law and Pharisees are labelled as snakes and the charge is doubled, as they are also labelled as the offspring of vipers (ö $\varphi \varepsilon 1 \varsigma$,

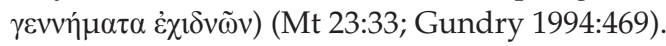

\section{Sorrow and lament for Jerusalem (Mt 23:37-39)}

The chapter concludes with a lament addressing Jerusalem. Jesus uses the well-known image of God's love for his people, namely of protecting them under his wings (Ps 17:8; 46:7; $57: 1 ; 61: 4 ; 63: 7 ; 91: 4)$. Jesus applies this image to demonstrate his efforts to take care of Jerusalem (Keener 2002:106). In the past, Jerusalem forsook the Lord, and he therefore forsook the city. Now Jerusalem forsakes Jesus, and the city and the temple will therefore be forsaken.

These three sections of Matthew 23 narrate the climactic response of Jesus to the foregoing challenges of the Jewish 19.Matthew 11:21: 'Woe to you, Korazin! Woe to you, Bethsaida!'.

20.The word u்roкрıтń [hypocrite] was mostly used for actors who consciously performed in a play. Batey (1971:563) indicates that Matthew consciously alludes to a úroкрıтn' as an actor and speculates whether Jesus' use of the term comes from his contact with the theatre in Sepphoris. Performing acts of religious deeds in a hypocritical manner implies that worship is turned into a spectacle. Hypocrites act with ethical pretence. The identity of truly honourable people does not lie in seeking public admiration but in enacting God's saving mercy.

21.The ancient Mediterranean people believed that people could see because light proceeded from their hearts through their eyes (Malina \& Rohrbauch 2003:64). On the other hand, with blind people darkness proceeded from their hearts through their eyes, indicating that there was something wrong in their hearts. Darkness was not considered as the absence of light, but as an objective evil reality.

22.In Isaiah 42:6-7 Israel is called to be a light for the Gentiles and to open the eyes of the blind (cf. Wis 18:4). According to Paul the Jewish people considered themselves to be a 'guide for the blind, a light for those who are in the dark' ( $R \mathrm{~m} 2: 19)$. 
leaders. The public nature of this response is emphasised with the beginning of the response where he warns his disciples against these leaders. While they aspire to gain honour with public recognition of their religious actions and teachings, Jesus exposes their hypocrisy and deception. Jesus then proceeds by addressing these leaders directly with a series of woe-sayings in which he repetitively calls them hypocrites and blind guides, terms that strongly denounce their pretence for public acclaim. The concluding judgement on Jerusalem's infidelity draws the response to a climax.

\section{Conclusion}

While the sentiment towards the Jewish leaders is negative throughout the Gospel, the conflict clearly intensifies during the week of the Passion, forming a crescendo of this conflict. Following Jesus' humble, yet royal entry into Jerusalem, he cleans and judges the temple. This judgement is symbolised and intensified by his cursing of the fig tree. This conduct of Jesus impairs the honour of the Jewish religious leaders and entices their antagonism. Their animosity towards Jesus is exposed and they respond by challenging Jesus' authority. The Matthean Jesus proceeds by telling three parables in which the unreliability of these leaders is exposed as they are identified with the oldest of the two sons in the first parable, the evil tenants in the second parable, and the invited guests to the wedding banquet who have rejected the invitation of the king. A series of three challenges follows in which Jesus takes on increasingly skilled teachers of his day. The Pharisees challenge him with a contentious political question on paying tax to the Caesar, the Sadducees on a controversial religious question on resurrection, and an expert of the Law on a dispute about the greatest commandment. However, in all three challenges Jesus emerges victoriously. The challenges are concluded by the counter question of Jesus about his authority, which leaves his opponents dumb and without any answer. This controversy dialogue culminates in Jesus's extensive criticism in Matthew 23. Firstly, Jesus addresses the crowds, warning them of the insincerity of these Jewish leaders. While they try to gain public recognition of their honour, their conduct is hypocritical, and their teachings are misleading. He then addresses the teachers of the Law and Pharisees directly and pronounces a series of woes in which he accuses them of being hypocritical and spiritually blind. He bemoans the destiny of Jerusalem, which as in the days of Zechariah, will be desolate as this city has opposed and killed the true prophets of God. While the Jewish leaders strived to gain public honour by challenging Jesus, Jesus publicly exposes their hypocrisy and lack of knowledge.

In Matthew 21-23 Jesus battles and defeats the challenges of his rivals. Jesus is highly vocal and assertive in his response. These scenes are followed by the eschatological discourse on the final judgement, which asserts his authority as ruler. This forms a strong contrast with the scenes to follow in which he is meek and silent in his trial and execution, a lamb to be slaughtered. He is seemingly defeated and stripped from all honour. However, he is finally victorious in his resurrection and authoritative Great Commission.

\section{Acknowledgements Competing interests}

The author declares that he has no financial or personal relationships that may have inappropriately influenced him in writing this article.

\section{References}

Batey, R., 1971, 'Jesus and the theatre', New Testament Studies 30, 563-574. https:// doi.org/10.1017/S0028688500013242

Blomberg, 1992, The New American commentary: Matthew, vol. 22, Broadman, Nashville, TN.

Brown, R.E., 1997, An introduction to the New Testament, Doubleday, New York.

Bruner, F.D., 2007, Matthew, a commentary, volume 2: The Churchbook Matthew 13-28, Eerdmans, Grand Rapids.

Bultmann, R., 1963, The history of the synoptic tradition, Blackwell, Oxford.

Carson, D.A., 1995, The expositor's Bible commentary with the New International Version of the Holy Bible: Matthew chapters 13 through 28, Zondervan e, Grand Rapids, MI.

Carter, W., 2000, 'Matthew 23:37-39', Interpretation 52(1), 66-68. https://doi. org/10.1177/002096430005400110

Combrink, H.J.B., 1983, 'The structure of the Gospel of Matthew as narrative', Tyndale Bulletin 34, 61-90.

Davies, W.D. \& Allison, D.C., 2004, Matthew 19-28, Clark, London. (International Critical Commentary, vol. 3)

De Silva, D.A., 2004, An introduction to the New Testament; Contents, methods and ministry formation, IVP Academic, Downers Grove, IL.

Esler, P.F., 2015, 'Intergroup conflict and Matthew 23: Towards responsible historical interpretation of a challenging text', Biblical Theology Bulletin 45(1), 38-95. https://doi.org/10.1177/0146107914564824

Foster, P., 2004, Community, law and mission in Matthew's Gospel, Mohr Siebeck, Tübingen. (WUNT, 2. Reihe, 177).

France, R.T., 2007, The Gospel of Matthew, Eerdmans, Grand Rapids, MI.

Garland, D.E., 1979, The intention of Matthew 23, Brill, Leiden.

Gerhardsson, B., 1976, 'The hermeneutic program in Matthew 22:37-40', in R. Hammerton-Kelly \& R. Scroggs (eds.), Jews, Greeks and Christians: Religious cultures in late antiquity, pp. 129-150, Brill, Leiden.

Gundry, R.H., 1994, Matthew: A commentary on his handbook for a mixed church under persecution, Eerdmans, Grand Rapids, MI.

Harlow, D.C., 2012, 'Early Judaism and early Christianity', in J.J. Collins \& D.C. Harlow (eds.), Early Judaism: A comprehensive overview, pp. 391-419, Eerdmans, Grand Rapids, MI.

Keener, G.S., 1999, A commentary on the Gospel of Matthew, Eerdmans, Grand Rapids, Michigan.

Keener, G.S., 2002, The IVP Bible Background Commentary: New Testament, IVP Academic, Downers Grove, IL.

Kingsbury, J.D., 1995, 'The developing conflict between Jesus and the Jewish leaders in Matthew's Gospel: A literary-critical study', in G. Stanton (ed.), The interpretation of Matthew, pp. 179-197, Clark, Edinburgh.

Kümmel, W.G., 1967, 'Die Weherufe über die Schriftgelehrten und Pharisäer (Matthäus 23,13-36)', in W.P. Eckert (ed.), Antijudaismus in Neuen Testament? pp. 135-147, Kaiser Verlag, München.

Luz, U., 1968, The Synoptic Gospels, Ktav, New York.

Malina, B.J. \& Rohrbauch, R.L., 2003, Social-science commentary on the Synoptic Gospels, Fortress, Minneapolis, MN.

Mason, S., 1990, 'Pharisaic dominance before $70 \mathrm{CE}$ and the Gospels' hypocrisy charge (Matt. 23:2-3), Harvard Theological Review 83, 363-381. https://doi. org/10.1017/S0017816000023841

Newport, K.G.C., 1995, The sources and Sitz im Leben of Matthew 23, JSNTSup 117 Academic Press, Sheffield.

Osborne, G.R., 2010, Matthew, Zondervan, Grand Rapids, MI. (Zondervan exegetical commentary on the New Testament).

Repschinski, B., 2000, The controversy stories in the Gospel of Matthew: Their redaction form and relevance for the relationship between the Matthean community and formative Judaism, Vandenhoeck \& Ruprecht, Göttingen.

Riesner, R., 1978, 'Der Aufbau der Reden im Matthäus-Evangelium', Theologische Beiträge 9, 177-178.

Saldarini, A.J., 1994, Matthew's Christian-Jewish Community, University of Chicago, Chicago.

Scholtz, J.J., 2015, 'Behold the glory of the King: The chiastic structures of Matthew $21-25$ ', In die Skriflig 49(1), Art. \#1856, 8 pages. https://doi.org/10.4102/ids. v49i1.1856

Sim, D.C., 1999, The Gospel of Matthew and Christian Judaism: The history and social setting of the Matthean community, Clark, Edinburg. 
Simmonds, A.R., 2009, “"Woe to you ... hypocrites!”: Re-reading Matthew 23:13-36', Bibliotheca Sacra 166, 336-349.

Stanton, G.N., 1993, A gospel for a new people: Studies in Matthew, Clark, Edinburgh.

Talbert, C.H., 2010, Matthew, Baker Academic, Grand Rapids, MI. (Paideia commentaries on the New Testament).

Toussaint, S.D., 1980, Behold the King: A study of Matthew, Kregel Publications, Grand Rapids, MI.

Turner, D.L., 2008, Baker exegetical commentary on the New Testament: Matthew Baker Academic, Grand Rapids, MI.

Viljoen, F.P., 2015, 'The double love commandment', In Luce Verbi 49(1), Art. \#1869, 11 pages. https://doi.org/10.4102/ids. v49i1.1869
Viljoen, F.P., 2016, 'The Matthean community within a Jewish religious society', HTS Theological Studies 72(4), a3418. https://doi.org/10.4102/hts.v72i4.3418

Viviano, B.T., 1990, 'Social world and community leadership: The case of Matthew 23:1-12, 34', JSNT 39, 3-21.

Wiefel, W., 1998, Das Evangelium nach Matthäus, Theologischer Handkommentar zum Neuen Testament, I,1Evangelische Verlagsanstalt, Leipzig.

Wilson, A.I., 2004, When will these things happen? A study of Jesus as judge in Matthew 21-25, Paternoster, Milton Keynes.

Witherington, B., 2006, Invitation to the New Testament: First things, Oxford University Press, Oxford.

Wright, A.T., 2013, 'Jewish identity, beliefs, and practices', in J.B. Green \& L.M. McDonald (eds.), The World of the New Testament: Cultural, social and historical contexts, pp. 310-423, Baker, Grand Rapids, MI. 